tions of the rotational motion of a rigid body in the Rodrigues Hamilton parameters. In this paper, this approach was used to solve the main problems of controlling the angular motion of a spacecraft: stabilization problems and terminal control problems. The article may be useful to developers of spacecraft attitude control systems.

Key words: Rodrig-Hamilton parameters, spacecraft, quaternion, orientation, dynamical equation for the quaternion.

Отримано: 28.11.2018

UDC 004.94

DOI: $10.32626 / 2308-5916.2018-18.65-73$

V. Ivaniuk, Cand. of Eng. Sciences, V. Ponedilok

Kamianets-Podilskyi Ivan Ohiienko National University

\title{
METHOD OF RESTORATION OF INPUT SIGNALS OF NONLINEAR DYNAMIC OBJECT WITH DESTRIBUTED PARAMETERS
}

The article deals with the method of signal restoration at the input of a nonlinear dynamic object with distributed parameters. To describe these objects, a universal mathematical model in the form of a Volterra integro-degree series has been chosen. The problem of signal restoration is reduced to the problem of solving the Volterra polynomial equation of the first kind. The numerical implementation of such models is suggested to be carried out using quadrature methods, in particular, the method of trapezoids. In order to increase the stability of the solution in the presence of noise interference in the input data, it is suggested to use the differential regularization operator, which allows the incorrectly set task to be transformed into a class of correct ones. The possibility of applying such an approach is studied in solving the Volterra polynomial integral equation of the second order type, which describes nonlinear dynamic objects with quadratic nonlinearity. The computational formulas for solving this type of equations are given in the article. The received nonlinear second-order algebraic equations after approximation of the initial equation by integral sums are solved by iterative methods with initial approximation in the form of a precalculated radical. The developed algorithms are implemented as software modules in the Matlab, with the help of which a number of computational experiments have been carried out. As an example, non-linear dynamic objects that contain static non-linearity of the second order and dynamic links that are typical for objects with distributed parameters have been chosen. Such links are: a semiintegral link, an attenuation link (semi-delay) and a semi-inertial 
link. On the basis of applying the equivalent transformations, the macromodels of objects with distributed parameters have been obtained in the form of a polynomial integral Volterra equation of the I kind of the second order with the kernels that describe the above-mentioned components. The results of the computational experiments, presented in the form of graphs, showed that the suggested approach can be effectively used in restoration of signals at the input of nonlinear dynamic objects with distributed parameters.

Key words: signal restoration, nonlinear dynamic objects with distributed parameters, Volterra series, Volterra equation of the first kind, Matlab / Simulink.

Introduction. While solving the problem of signal restoration at the input of nonlinear dynamical systems, there is usually a need to solve Volterra nonlinear equations of the first kind $[1,3,5,6]$. Applying of integro-degree Volterra series, which is a universal mathematical model for describing nonlinear dynamical system [4],

$$
y(t)=\int_{0}^{t} K_{1}(t, \tau) x(\tau) d \tau+\int_{0}^{t} \int_{0}^{t} K_{2}\left(t, \tau_{1}, \tau_{2}\right) x\left(\tau_{1}\right) x\left(\tau_{2}\right) d \tau_{1} d \tau_{2}+\ldots,
$$

where $x(t), y(t)$ - respectively, the input and output signals of the object, $t$ - time of the transient process, $K_{i}\left(t, \tau_{1}, \ldots, \tau_{i}\right)$ - Volterra kernel, makes it possible to simplify nonlinear mathematical models by converting them to a quasi-linear type $[1,4]$. It also should be noted that the applying of Volterra series will allow to solve the problems of modeling dynamic objects with lumped and distributed parameters based on the same means, because for these objects, mathematical models will differ only in the form of kernels $[2,6]$.

In general, the problem of restoration can be reduced to the Volterra polynomial integral equations of the 1st kind (1). In the linear variant, we will have a classical form of the integral of Volterra equation of the $1^{\text {st }}$ kind with one kernel $K_{1}[1,4]$. The invalidity of signal restoration problem requires the applying of indirect approaches to the solving of integral equations of the first kind. The most effective approach to solving these problems is the appliance of regularization methods, the application of which will allow obtaining the sustainable solutions to the problem of restoration $[3,6]$.

Therefore, the development of new methods for solving Volterra polynomial integral equations of the $1^{\text {st }}$ kind based on regularization algorithms for restoration of input signals of nonlinear dynamic objects, both with lumped and distributed parameters, is an urgent task.

The aim of the work is to develop an effective method for solving inverse problems of dynamics of nonlinear objects with distributed parameters by solving Volterra polynomial integral equations of the first kind. 
The main part. Solving of this problem will be considered on the example of solving the Volterra polynomial integral equation of the 2nd kind:

$$
\int_{0}^{t} K_{1}(t, \tau) x(\tau) d \tau+\int_{0}^{t} \int_{0}^{t} K_{2}\left(t, \tau_{1}, \tau_{2}\right) x\left(\tau_{1}\right) x\left(\tau_{2}\right) d \tau_{1} d \tau_{2}=y(t) .
$$

The problem of regenerating a signal that is altered by a nonlinear dynamic object is incorrect, and using of classical methods for solving such problems in the presence of noise interference in signals does not allow obtaining stable solutions with the necessary accuracy. It is suggested to use a differential regularization operator of first kind $\alpha \frac{d x}{d t}$, where $\alpha$ - a parameter of regularization. In this case the solution of Volterra polynomial equation is reduced to solving of the following integro-differential equation:

$$
\alpha \frac{d x}{d t}+\int_{0}^{t} K_{1}(t, \tau) x(\tau) d s+\int_{0}^{t} \int_{0}^{t} K_{2}\left(t, \tau_{1}, \tau_{2}\right) x\left(\tau_{1}\right) x\left(\tau_{2}\right) d \tau_{1} d \tau_{2}=y(t) .
$$

The given problem is suggested to be solved by replacing the integrals in (3) quadrature formulas, which allows to obtain a number of advantages, in particular, the simplicity of implementation and high stability of computational algorithms due to the regularizing properties of choosing the quadrature step [6]. Applying to (3) the method of trapezoids and difference formula of the first kind [1,3], the following will $\mathrm{b}$ received:

$$
\begin{gathered}
\alpha \frac{x\left(t_{i}\right)-x\left(t_{i-1}\right)}{h}+\frac{1}{2} h K_{1}\left(t_{i}, t_{i}\right) x\left(t_{i}\right)+\sum_{j=1}^{i-1} h K_{1}\left(t_{i}, t_{j}\right) x\left(t_{j}\right)+ \\
+\frac{1}{2} h K_{1}\left(t_{i}, t_{0}\right) x\left(t_{0}\right)+\frac{1}{4} h^{2} K_{2}\left(t_{i}, t_{0}, t_{0}\right) x\left(t_{0}\right) x\left(t_{0}\right)+ \\
+\frac{1}{2} h^{2} \sum_{j=1}^{i-1}\left(K_{2}\left(t_{i}, t_{0}, t_{j}\right)+K_{2}\left(t_{i}, t_{j}, t_{0}\right)\right) x\left(t_{0}\right) x\left(t_{j}\right)+ \\
+h^{2} \sum_{j=1}^{i-1} \sum_{g=1}^{i-1} K_{2}\left(t_{i}, t_{j}, t_{g}\right) x\left(t_{j}\right) x\left(t_{g}\right)+ \\
+\frac{1}{4} h^{2}\left(K_{2}\left(t_{i}, t_{i}, t_{0}\right)+K_{2}\left(t_{i}, t_{0}, t_{i}\right)\right) x\left(t_{0}\right) x\left(t_{i}\right)+ \\
+\frac{1}{2} h^{2} \sum_{j=1}^{i-1}\left(K_{2}\left(t_{i}, t_{i}, t_{j}\right)+K_{2}\left(t_{i}, t_{j}, t_{i}\right)\right) x\left(t_{j}\right) x\left(t_{i}\right)+ \\
+\frac{1}{4} h^{2} K_{2}\left(t_{i}, t_{i}, t_{i}\right) x\left(t_{i}\right) x\left(t_{i}\right)=y\left(t_{i}\right),
\end{gathered}
$$


where $i=\overline{1 . . n}, h=t_{i}-t_{i-1}$. The (4) should be rewritten by grouping the summands for the target value $x\left(t_{i}\right)$ :

$$
\begin{gathered}
\frac{1}{4} h^{2} K_{2}\left(t_{i}, t_{i}, t_{i}\right) x^{2}\left(t_{i}\right)+ \\
+\left(\frac{1}{4} h^{2}\left(K_{2}\left(t_{i}, t_{i}, t_{0}\right)+K_{2}\left(t_{i}, t_{0}, t_{i}\right)\right) x\left(t_{0}\right)+\right. \\
+\frac{1}{2} h^{2} \sum_{j=1}^{i-1}\left(K_{2}\left(t_{i}, t_{i}, t_{j}\right)+K_{2}\left(t_{i}, t_{j}, t_{i}\right)\right) x\left(t_{j}\right)+ \\
\left.+\frac{1}{2} h K_{1}\left(t_{i}, t_{i}\right)+\frac{\alpha}{h}\right) x\left(t_{i}\right)+ \\
+\sum_{j=1}^{i-1} h K_{1}\left(t_{i}, t_{j}\right) x\left(t_{j}\right)+\frac{1}{2} h K_{1}\left(t_{i}, t_{0}\right) x\left(t_{0}\right)+ \\
+\frac{1}{4} h^{2} K_{2}\left(t_{i}, t_{0}, t_{0}\right) x\left(t_{0}\right) x\left(t_{0}\right)+ \\
+\frac{1}{2} h^{2} \sum_{j=1}^{i-1}\left(K_{2}\left(t_{i}, t_{0,}, t_{j}\right)+K_{2}\left(t_{i}, t_{j,}, t_{0}\right)\right) x\left(t_{0}\right) x\left(t_{j}\right)+ \\
+h^{2} \sum_{j=1}^{i-1} \sum_{g=1}^{i-1} K_{2}\left(t_{i}, t_{j}, t_{g}\right) x\left(t_{j}\right) x\left(t_{g}\right)-\frac{\alpha}{h} x\left(t_{i-1}\right)-y\left(t_{i}\right)=0
\end{gathered}
$$

$n$ quadratic equations (5) are solved sequentially on the basis of the iterative method, and, for the initial approximation the root of the previous equation is taken [3].

Software implementation of the method. On the basis of the suggested method, a software tool for restoration of signals in the form of a program module for solving the Volterra polynomial integral equation of the $1^{\text {st }}$ kind of the second order by the method of trapezoids was developed in Matlab environment - a function

$$
\mathrm{x}=\text { invvolterraseries2treg (kern, y, t, h, alpha), }
$$

where kern - kernel of Volterra series, which are given as an array of functions; $\mathrm{y}$ - ordinate vector $y(t) ; \mathrm{t}$ - vector of values of time variable $t ; \mathrm{h}$ - simulation step, alpha - regularization parameter.

Structural and algorithmic method of obtaining solutions. Let's consider a dynamic object with non-inertial nonlinearity, which is described by the structural scheme represented in Fig. 1. On a structure diagram $A(x(t))$ - linear component, $F(u(t))$ - nonlinear component. 


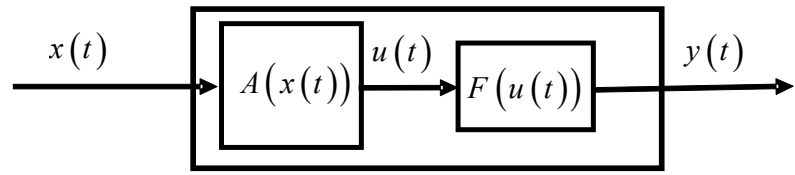

Fig. 1. Structure diagram of object model

For objects with distributed parameters the following basic typical irrational and transcendental links can be distinguished, they are defined by the operator $A(x(t))$ : semi-integral, semi-inertial, delaying and damping (or semi-delaying) [2]. In table 1 the Volterra operator $A(x(t))$ for the above links is described.

Table 1

A set of typical irrational and transcendental units

\begin{tabular}{|l|c|}
\hline \multicolumn{1}{|c|}{ Link name } & Volterra operator \\
\hline Semi-integral & $u(t)=\int_{0}^{t} \frac{k}{\sqrt{\pi \tau}} x(t-\tau) d \tau$ \\
\hline Semi-inertial & $u(t)=\int_{0}^{t} \frac{k}{T}\left(\sqrt{\frac{T}{\pi k}}-e^{\frac{\tau}{T}} \operatorname{erfc} \sqrt{\frac{\tau}{T}}\right) x(t-\tau) d \tau$ \\
\hline Delaying & $u(t)=\int_{0}^{t} \delta(\tau) x(t-\tau) d \tau$ \\
\hline $\begin{array}{l}\text { Damping (semi- } \\
\text { delaying) }\end{array}$ & $u(t)=\int_{0}^{t} 0.5 \sqrt{\frac{T}{\pi \tau^{3}}} e^{-\frac{T}{4 \tau}} x(t-\tau) d \tau$ \\
\hline$k, T-$ constants & \\
\hline
\end{tabular}

In the case if a non-inertial nonlinear element $F(u(t))$, can be represented by a Taylor series or a polynom, the macromodel in the form of a structural diagram (Fig. 1) is represented by Volterra serries (1) [4].

Computational experiments. Let's consider the case when the linear part is determined by the semi-integral link, and the nonlinear part has the form: $F(u(t))=u+u^{2}$. After applying equivalent transformations [4] the macromodel in the form of an integro-degree series Volterra is obtained as a result:

$$
y(t)=\int_{0}^{t} \frac{k}{\sqrt{\pi \tau}} x(t-\tau) d \tau+\int_{0}^{t} \int_{0}^{t} \frac{k^{2}}{\pi \sqrt{\tau_{1} \tau_{2}}} x\left(t-\tau_{1}\right) x\left(t-\tau_{2}\right) d \tau_{1} d \tau_{2} .
$$

At numerical realization of the received model at the point of zero of kennel are singular, therefore instead of zero point the value of $h$ modeling 
step is taken. With the help of the developed software assets, a number of computational experiments have been conducted. In fig. 2 a signal with noise interference is shown, on the basis of which the input signal is restored. In fig. 3 the accurate and restored signals are provided.

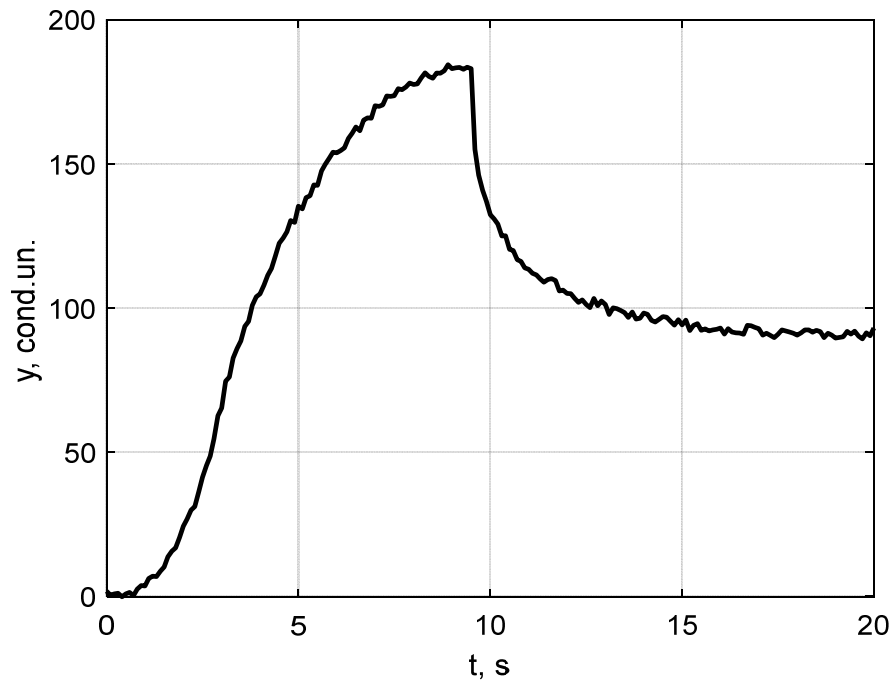

Fig. 2. Signal on the output of the nonlinear dynamic object (6)

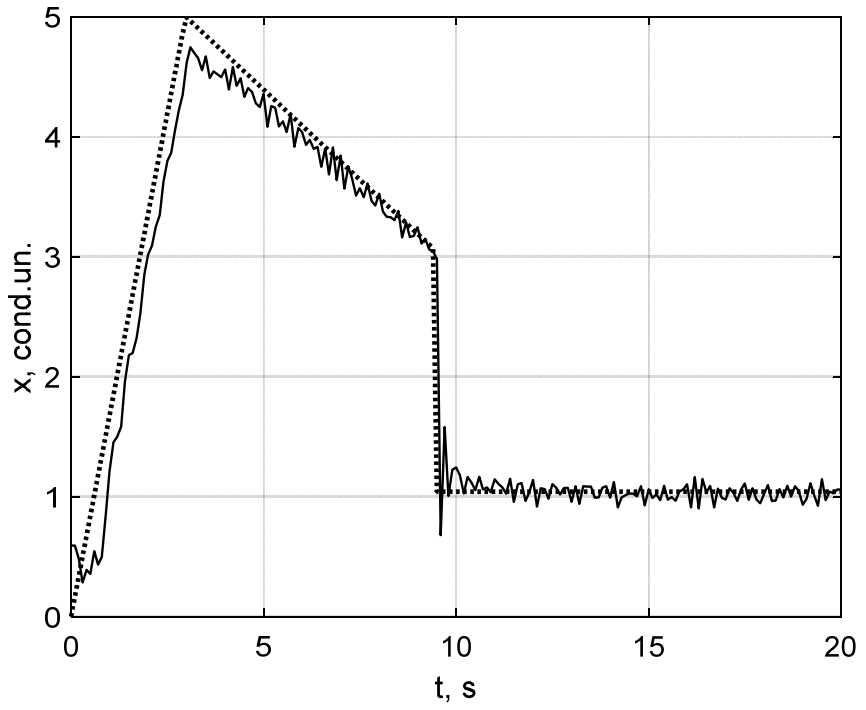

Fig. 3. Signal on the output of the nonlinear dynamic object (6) 
In the case when the linear part is determined by the semi-inertial link, the macro-model in the form of the integro-degree Volterra series has the form:

$$
\begin{gathered}
y(t)=\int_{0}^{t} \frac{k}{T}\left(\sqrt{\frac{T}{\pi k}}-e^{\frac{\tau}{T}} \operatorname{erf} c \sqrt{\frac{\tau}{T}}\right) x(t-\tau) d \tau+ \\
+\int_{0}^{t} \int_{0}^{t} \frac{k^{2}}{T^{2}}\left(\sqrt{\frac{T}{\pi k}}-e^{\frac{\tau_{1}}{T}} \operatorname{erf} \sqrt{\frac{\tau_{1}}{T}}\right)\left(\sqrt{\frac{T}{\pi k}}-e^{\frac{\tau_{2}}{T}} \operatorname{erf} \sqrt{\frac{\tau_{2}}{T}}\right) x\left(t-\tau_{1}\right) x\left(t-\tau_{2}\right) d \tau_{1} d \tau_{2} .
\end{gathered}
$$

On Fig. 4 the results of signal restoration are given.

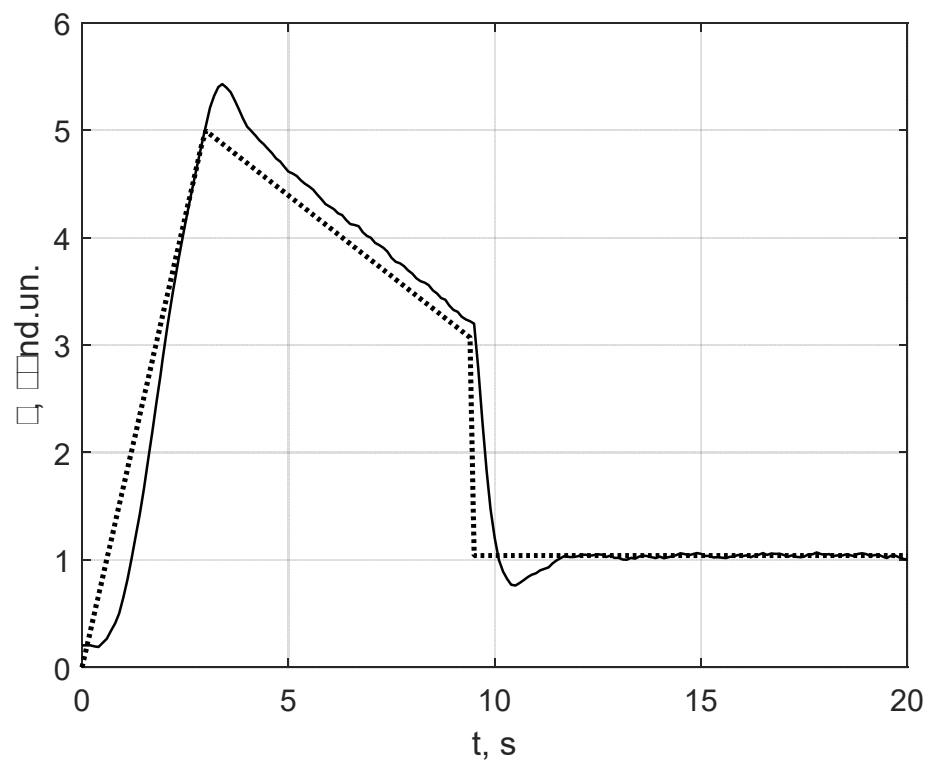

Fig. 4. Signal on the output of the nonlinear dynamic object (7) (..............-accurate, - restored)

The macro model in the form of the integro-degree Volterra series, providing that the linear part is determined by the link of delay, has the form:

$$
\begin{gathered}
y(t)=\int_{0}^{t} 0.5 \sqrt{\frac{T}{\pi \tau^{3}}} e^{-\frac{T}{4 \tau}} x(t-\tau) d \tau= \\
+\int_{0}^{t} \int_{0}^{t} 0.5^{2} \frac{T}{\pi} \sqrt{\frac{1}{\tau_{1}^{3} \tau_{2}^{3}}} e^{-\frac{T\left(\tau_{1}+\tau_{2}\right)}{4 \tau_{1} \tau_{2}}} x\left(t-\tau_{1}\right) x\left(t-\tau_{2}\right) d \tau_{1} d \tau_{2} .
\end{gathered}
$$

On Fig. 5 the results of signal restoration are given. 


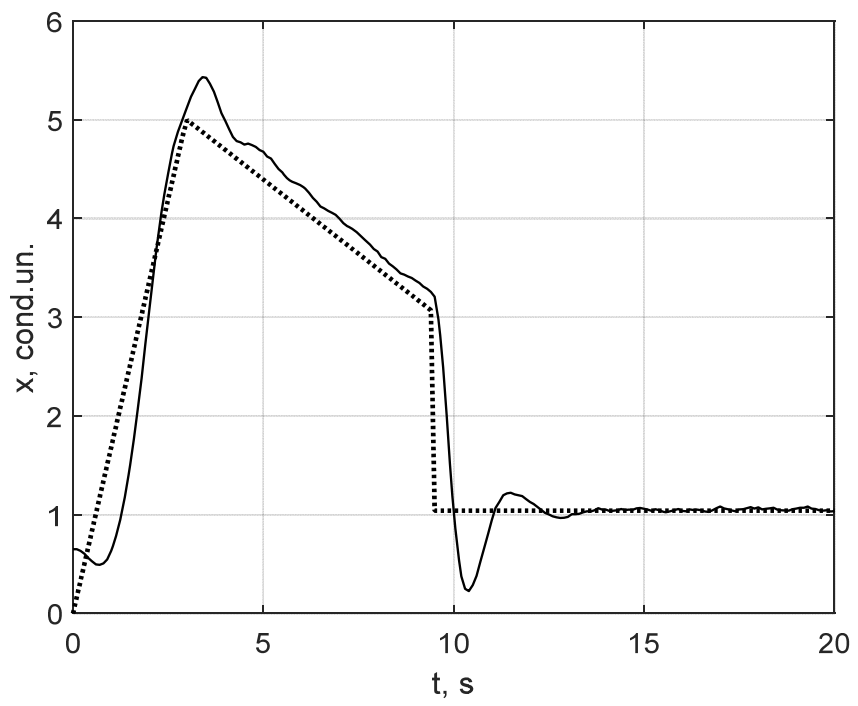

Fig. 5. Signal on the output of the nonlinear dynamic object (8)

$$
\text { (............ - accurate, — - restored) }
$$

Conclusions. The computational experiments have shown that the developed regularization method for solving Volterra polynomial integral equations of the first kind on the basis of on the introduction of a differential regularization operator allows obtaining high accuracy in regenerating of signals at the input of nonlinear dynamic objects with distributed parameters in the presence of noise interference.

\section{References:}

1. Ivaniuk V. A. Integral models of irrational and transcendental links / V. A. Ivaniuk, V. O. Tykhokhod, S. O. Protasov // Mathematical and computer simulation. Series: Engineering sciences : collection of research papers / Kamianets-Podilskyi National Ivan Ohiienko University, V. M. Hlushkov Institute of Cybernetics of the National Academy of Sciences of Ukraine, Kamianets-Podilskyi : Kamianets-Podilskyi National Ivan Ohiienko University, 2011. - ISSUE 5. - P. 101-109.

2. Ivanyuk V. Solving inverse problems of dynamics of nonlinear objects based on the Volterra series / V. Ivanyuk, V. Ponedilok, J. Sterten // Computational problems of electrical engineering - Lviv : Lviv Polytechnic National University, 2016. - Vol. 6, No. 1. - P. 9-16.

3. Ponedilok V. Regularization Method of Restoration of Input Signals of Nonlinear Dynamic Objects that Determined by Integro-Degree Volterra Series / V. Ponedilok // Mathematical and computer modelling. Series: Technical sciences: scientific journal / V. M. Glushkov Institute of Cybernetics of the National Academy of Sciences of Ukraine, Kamianets-Podilskyi National Ivan Ohiienko University. - Kamianets-Podilskyi : Kamianets-Podilskyi National Ivan Ohiienko University, 2018. — ISSUE 17. - P. 133-140. 
4. Pupkov K. A. Functional series in the theory of nonlinear systems / K. A. Pupkov, V. I. Kapalin, A.S. Yushchenko. - M. : Nauka, 1976. - 448 p.

5. Solodusha S. V. Simulation of automatic control systems based on Volterra polynomials / S. V. Solodusha // Simulation and analysis of information systems. - 2012. - № 1. - P. 60-68.

6. Verlan A. F. Integral equations: Methods. Algorithms. Programs: Reference book / A. F.Verlan, V. S. Sizikov. — K. : Nauk. dumka, 1986. — 548 p.

\section{МЕТОД ВІДНОВЛЕННЯ СИГНАЛУ НА ВХОДІ НЕЛІНІЙНОГО ДИНАМІЧНОГО ОБ'ЄКТА 3 РОЗПОДІЛЕНИМИ ПАРАМЕТРАМИ}

У статті розглянуто метод відновлення сигналу на вході нелінійного динамічного об'єкта з розподіленими параметрами. Для опису даних об'єктів обрано універсальну математичну модель у вигляді інтегро-степеневого ряду Вольтерри. Задача відновлення сигналу зводиться до задачі розв'язування поліноміального рівняння Вольтерри першого роду. Чисельну реалізацію таких моделей пропонується здійснювати 3 використанням квадратурних методів, зокрема, методу трапецій. Для збільшення стійкості розв'язку при наявності шумових завад у вхідних даних запропоновано використання диференціального регуляризаційного оператора, який дозволяє некоректно поставлену задачу перевести у клас коректних. Можливість застосовування такого підходу досліджено при розв'язуванні поліноміального інтегрального рівняння Вольтерри I роду другого порядку, яке описує нелінійні динамічні об'єкти із квадратичною нелінійністю. В статті наведено обчислювальні формули для розв'язання даного типу рівнянь. Отримані нелінійні алгебраїчні рівняння другого порядку після апроксимації вихідного рівняння інтегральними сумами розв'язуються ітераційними методами із початковим наближенням у вигляді попередньо обчисленого кореня. Розроблені алгоритми реалізовано у вигляді програмних модулів в середовищі Matlab, за допомогою яких проведено ряд обчислювальних експериментів. Як приклад, вибрано нелінійні динамічні об'єкти, які містять статичну нелінійність другого порядку та динамічні ланки, які є типовими для об'єктів із розподіленими параметрами. Такими ланками $є$ : напівінтегральна ланка, ланка затухання (напівзапізнення) та напівінерційна ланка. На основі застосування еквівалентних перетворень отримано макромоделі об'єктів з розподіленими параметрами у вигляді поліноміального інтегрального рівняння Вольтерри I роду другого порядку із ядрами, які описують вказані вище ланки. Результати обчислювальних експериментів, які наведено у вигляді графіків, показали, що запропонований підхід може ефективно використовуватись при відновленні сигналів на вході нелінійних динамічних об'єктів із розподіленими параметрами.

Ключові слова: відновлення сигналів, нелінійні динамічні об'єкти з розподіленими параметрами, ряди Вольтерри, рівняння Вольтерри I pody, Matlab/Simulink.

Отримано: 12.11.2018 